\title{
Penggunaan Vertical Loop pada Perawatan Gigi Berjejal Parah dan Crossbite Anterior dengan Teknik Begg
}

\author{
Herna Juliana Nainggolan*, Wayan Ardhana**, dan Christnawati** \\ * Program Studi Ortodonsia PPDGS Fakultas Kedokteran Gigi Universitas Gadjah Mada \\ ** Bagian Ortodonsia, Fakultas Kedokteran Gigi Universitas Gadjah Mada \\ *JI Denta no 1 Sekip Utara Yogyakarta, e-mail: hernajuliana@ymail.com
}

\begin{abstract}
ABSTRAK
Gigi berjejal dapat terjadi pada semua klasifikasi maloklusi. Perawatan gigi berjejal berat dengan teknik Begg menggunakan vertical loop untuk meningkatkan kelentingan busur labial supaya dapat terpasang pada gigi berjejal sehingga levelling dan unravelling gigi anterior dapat tercapai. Tujuan artikel ini untuk menerangkan manfaat dari vertical loop pada kasus gigi berjejal berat. Pada artikel ini disajikan dua kasus gigi berjejal parah dan crossbite. Kasus pertama: laki-laki 17 tahun tidak percaya diri karena berjejal dan gingsul. Diagnosis: maloklusi Angle klas III subdivisi tipe skeletal klas III dengan maksila retrusif dan mandibula prognatik, gigi berjejal parah dan crossbite anterior. Kasus kedua: perempuan 18 tahun, mengeluhkan gigi berjejal, sulit dibersihkan dan gusi sering berdarah. Diagnosis: Maloklusi Angle klas I tipe skeletal klas I dengan bimaksiler retrusif dan bidental protrusif gigi berjejal berat dan crossbite anterior. Pada kedua kasus dilakukan perawatan dengan alat ortodontik cekat teknik Begg, pada tahap pertama digunakan archwire diameter 0,014" dengan vertical loop untuk koreksi gigi malposisi berupa gigi berjejal, membuka dan menutup ruang gigi anterior dengan menggerakkan gigi ke arah mesiolabial dan labiolingual sehingga gigi berjejal dan crossbite anterior dapat terkoreksi. Hasil: Koreksi inklinasi gigi-gigi rahang atas dan bawah, overjet dan overbite dipertahankan, penutupan sisa ruang, koreksi aksial gigi-gigi dan perbaikan interdigitasi sesuai dengan oklusi normal. Kesimpulan dari penggunaan vertical loop pada perawatan ortodontik cekat dengan teknik Begg menunjukkan sangat efektif dalam mengoreksi gigi berjejal berat dan crossbite anterior.
\end{abstract}

Maj Ked Gi; Desember 2013; 20(2):231-238.

Kata Kunci: Vertical loop, berjejal parah, crossbite anterior, teknik Begg

\begin{abstract}
The Use of Vertical Loops to Treat Severely Crowded Teeth and Cross Bite Anterior with Begg Technique. Crowded teeth can occur in all classifications of malocclusion. The treatment of severe crowded teeth with Begg technique using the vertical loop is to increase the resilience of the archwire labial, so it can facilitate to levelling and unravelling anterior teeth. The aim of this article is to explain the advantage of using vertical loop to correct severe crowding teeth with anterior crossbite. We reported two cases of severe crowding with anterior crossbite. The first case was a 17 year old boy with the main complaint was not confident due to the anterior teeth severe crowding with high canine. The diagnosis was Angle Class III subdivision malocclussion type, class III skeletal pattern combined with retrusive maxilla and prognatic mandible, severe crowding teeth and anterior crossbite. The second case was an 18 years old female complaining of severe crowding with periodontal problems. She was diagnosed with Class I Angle malocclusion with Class I skeletal pattern bimaxiller retrusion and bidental protrusion acompanied by severe crowding teeth and anterior crossbite. Both of cases were treated using Begg technique and orthodontic device. The first step used archwire with dimeter 0,014" Australian wire with vertical loop to correct the crowding, open and close of anterior space by moving the teeth toward mesiolabial and labiolingual thus the crowding and anterior crossbite can be corrected. The result showed both patient anterior teeth are in correct inclination, overjet and overbite can be maintained, the space was closed and the interdigitation of the posterior teeth accordance with normal occlusion. It was concluded that using vertical loop in orthodontic treatment with Begg techniques showed effectively correcting the severe crowding teeth and anterior crossbite cases.

Maj Ked Gi; Desember 2013; 20(2): 231-238.
\end{abstract}

Key words: vertical loop, severe crowding, anterior crossbite, Begg technique

\section{PENDAHULUAN}

Gigi berjejal adalah suatu keadaan susunan gigi berdesak-desak dan tumpang tindih dalam lengkung gigi, terjadi akibat penyimpangan posisi gigi pada masing-masing rahang ataupun pada kedua rahang. ${ }^{1}$ Penyimpangan dapat berupa ketidak teraturan susunan gigi pada regio anterior berupa gigi berjejal dengan atau tanpa disertai protrusif.' Berdasarkan 
besar kekurangan ruang pengaturan dalam lengkung ,gigi berjejal dikelompokkan dalam tiga kategori yaitu,derajat ringan, sedang dan derajat parah. ${ }^{2}$

Crossbite anterior merupakan kelainan oklusi pada bidang transversal,yang terjadi pada satu gigi atau beberapa gigi pada lengkung gigi. Posisi oklusi gigi-gigi anterior maksila lebih kearah lingual atau palatal dari gigi anterior mandibula. Maloklusi crossbite anterior dapat disebabkan faktor gigi, skeletal dan fungsional.

Teknik Begg merupakan suatu teknik perawatan ortodontik yang menggunakan gaya yang ringan dengan archwire berpenampang bulat dan bracket ribbon arch. Archwire bergerak bebas tanpa friksi dan menghasilkan gerak tipping mahkota secara bebas. ${ }^{4}$ Perawatan ortodontik teknik Begg pada umumnya terdiri dari tiga tahap, tahap I biasanya digunakan archwire dengan vertical loop pada interproksimal dari gigi anterior akan memperpanjang kawat, meningkatkan kelentingan hingga archwire dapat terpasang hampir di semua gigi berjejal, dengan kekuatan yang ringan menggerakkan gigi ke segala arah secara bersamaan. ${ }^{1,4}$ Levelling dan unraveling dapat tercapai dengan gaya simultan mendorong gigi ke distal akibat tarikan elastik intermaksiler, mengatur malposisi gigi berupa gigi berjejal, membuka dan menutup ruang gigi anterior dengan menggerakkan gigi ke arah mesial, distal,labial, lingual. ${ }^{5,1}$ Archwire dengan vertical loop mengoreksi gigi-gigi berjejal lebih cepat, lebih mudah dan mengurangi rasa sakit bagi pasien bila dibandingkan dengan pemakaian archwire yang datar (plain archwire). ${ }^{5.4}$ Pemakaian vertical loop dan elastik intermaksiler klas II

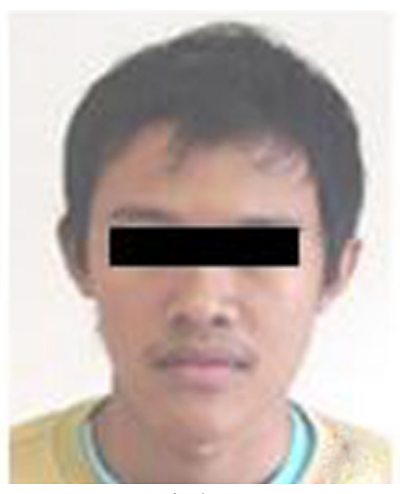

(A) menyebabkan tipping distal gigi anterior dan mengisi ruang bekas gigi pencabutan untuk mereduksi jarak gigi ataupun mengoreksi malposisi gigi . ${ }^{6.4}$ Australian wire 0.014" cenderung menggerakkan gigi ke arah labial sebelum gigi kaninus bergerak ke distal untuk menahan gerakan gigi ke arah labial. ${ }^{5.7}$

Tahap 2 space closing, bertujuan menutup sisa ruang pencabutan dengan meneruskan gerakan tipping gigi anterior ke palatal atau lingual dan mesialisasi gigi molar secara bodily. Tahap 3 bertujuan untuk mengoreksi inklinasi aksial dan interdigitasi gigi rahang atas dan rahang bawah. ${ }^{6.1}$

Vertical loop memberikan aksi horizontal, gerakan mesial-distal, bukal dan lingual., ${ }^{5,8}$ Berfungsi mengatur letak malposisi gigi incisivus bersamaan dengan tipping distal terhadap gigi kaninus untuk membuka dan menutup ruang, rotasi gigi. Bentuk dan jumlahnya tergantung keperluan dalam pengaturan gigi incisivus." Artikel ini akan menyajikan dua kasus, yang keduanya dirawat dengan alat ortodontik cekat teknik Begg, pada tahap pertama digunakan archwire diameter 0,014" dengan vertical loop untuk koreksi gigi malposisi berupa gigi berjejal, membuka dan menutup ruang gigi anterior dengan menggerakkan gigi ke arah mesiolabial dan labiolingual sehingga gigi berjejal dan crossbite anterior dapat terkoreksi.

\section{STUDI KASUS}

Kasus I: Pasien laki-laki, 17 tahun datang ke klinik ortodonsia RSCM Prof. Soedomo FKG UGM dengan keluhan tidak percaya diri karena gigi tidak rapi, berjejal dan gingsul (Gambar 1 dan 2).

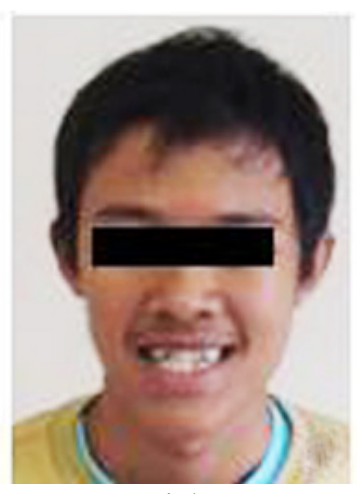

(B)

Gambar 1. Fotogram muka dan intra oral gigi-geligi sebelum perawatan kasus I Ket: (A) Fotogram muka tampak depan, (B) Fotogram muka tampak depan senyum 
Pemeriksaan intraoral memperlihatkan hygiene mulut baik, bentuk lengkung gigi rahang atas $U$ asimetris, sedangkan rahang bawah bentuk $\mathrm{U}$ simetris. Midline rahang atas bergeser ke kanan sebesar 3,54 mm. Hubungan gigi molar pertama kanan klas III Angle sedangkan relasi molar pertama kiri klas I Angle. Hubungan gigi kaninus kanan klas II, kaninus kiri klas I. Overjet 2,0mm dan overbite $2,5 \mathrm{~mm}$. Pasien mempunyai riwayat rampan karies pada periode gigi desidui. Pada periode gigi bercampur mengalami prolong retensi dan kebiasaan menggigit pena pada sisi kanan mulai SMP sampai saat datang. Hasil analisis sefalometri menyimpulkan hubungan skeletal klas III dengan maksila retrusif dan mandibula prognatik disertai protrusif incisivus atas. Analisis ruang dengan determinasi lengkung dan set up model kesling, menyusun lengkung ideal,tidak dilakukan retraksi, koreksi midline, overjet dan overbite tetap dilakukan pencabutan empat premolar pertama. Kekurangan ruang rahang atas sebesar 6.73 pada sisi kiri dan terdapat sisa ruang pada sisi kiri atas $1.88 \mathrm{~mm}$ dan sisi kanan kurang ruang 11.75 sisa ruang $0 \mathrm{~mm}$, pada rahang bawah dengan mengoreksi gigi 35 mesioversi dan gigi 43 yang distoversi terdapat sisa ruang pada sisi kanan $0 \mathrm{~mm}$ dan sisi kiri $3.98 \mathrm{~mm}$. Sisa ruang ditutup dengan mesialisasi gigi-gigi posterior pada sisi kiri agar hubungan molar tetap baik pada sisi kiri maupun sisi kanan.

Diagnosis: maloklusi Angle klas III subdivisi tipe skeletal klas III dengan maksila dan mandibula prognatik, gigi berjejal parah dan crossbite anterior.

Rencana perawatan pada kasus ini adalah motivasi untuk menghilangkan kebiasaan buruk,analisis ruang. Koreksi malrelasi dan malposisi gigi individual rahang atas dan rahang bawah dilakukan dengan alat cekat teknik Begg sistem bonding. Vertical loop digunakan pada gigi-gigi anterior untuk membuka ruang sehingga gigigigi berjejal dapat menempati lengkung ideal dan perbaikan crossbite anterior, setelah itu dilakukan penyesuaian oklusi dilanjutkan dengan pemakaian retainer.

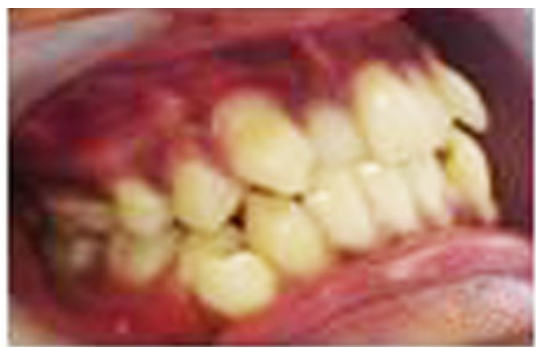

(A)

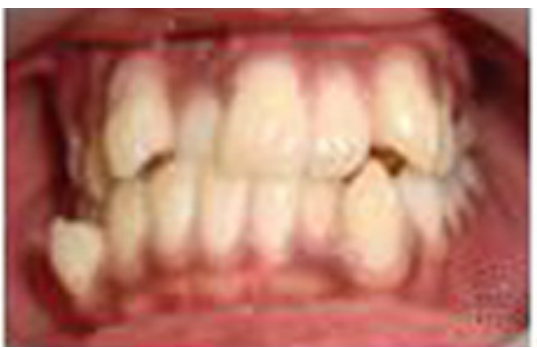

(B)

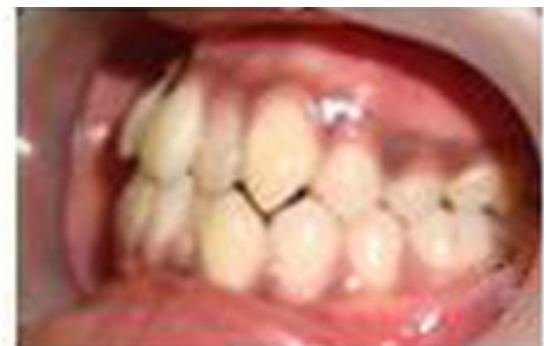

(C)

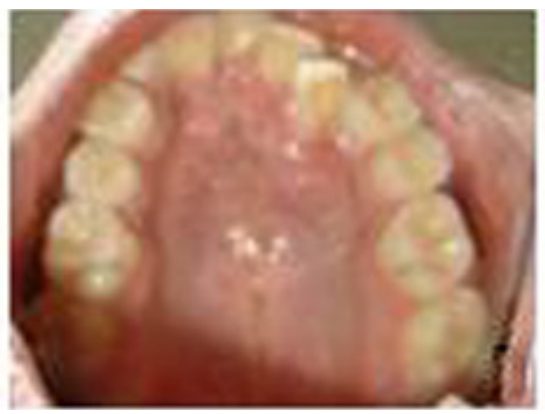

(D)

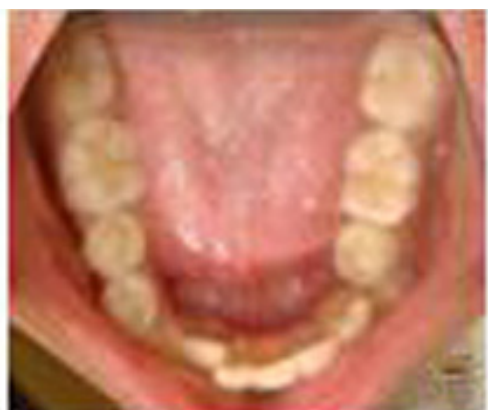

(E)

Gambar 2 . Fotogram intra oral gigi-geligi sebelum perawatan kasus I Ket : (A) dan (C) Fotogram gigi geligi tampak samping, (B) Fotogram gigi geligi tampak depan; (D) Fotogram intra oral gigi geligi rahang atas; (E) Fotogram intra oral gigi geligi rahang bawah 


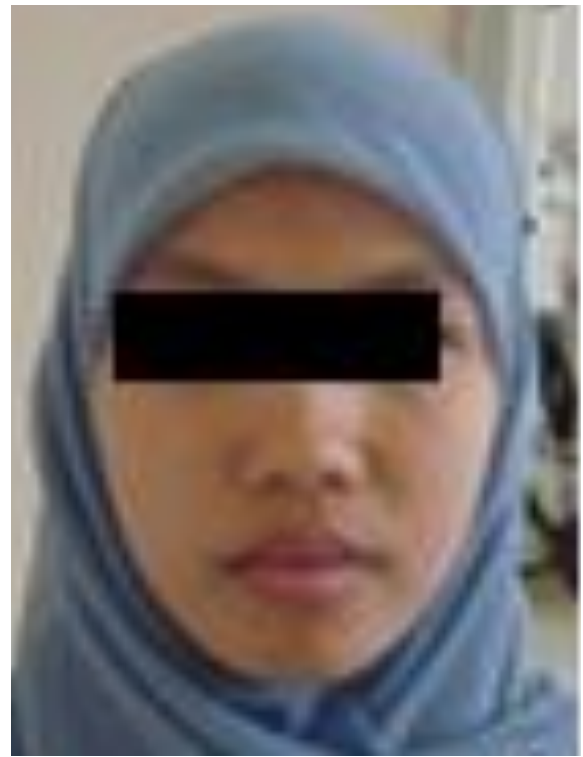

(A)

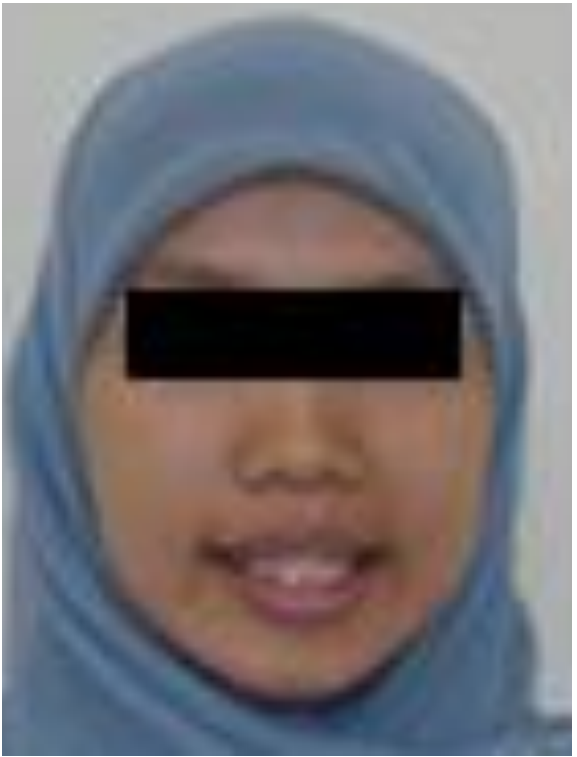

(B)

Gambar 3. Fotogram muka dan intra oral gigi-geligi sebelum perawatan kasus II Ket: (A) Fotogram muka tampak depan (B) Fotogram muka tampak depan senyum

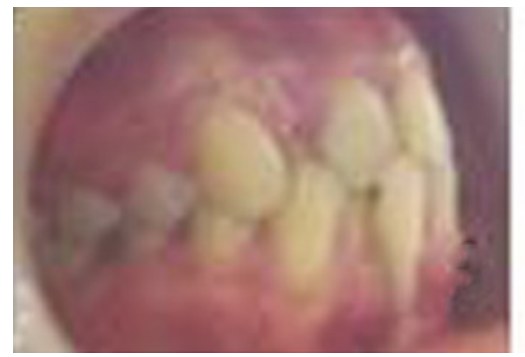

(A)

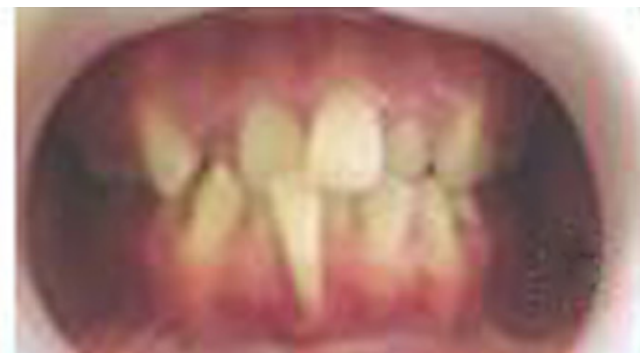

(B)

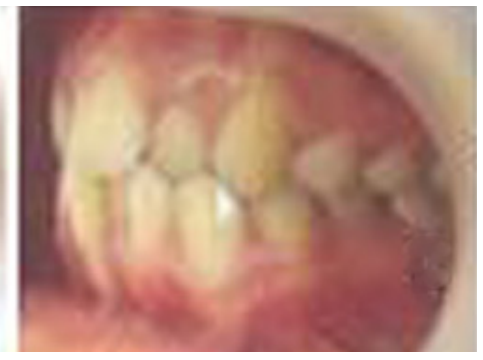

(C)

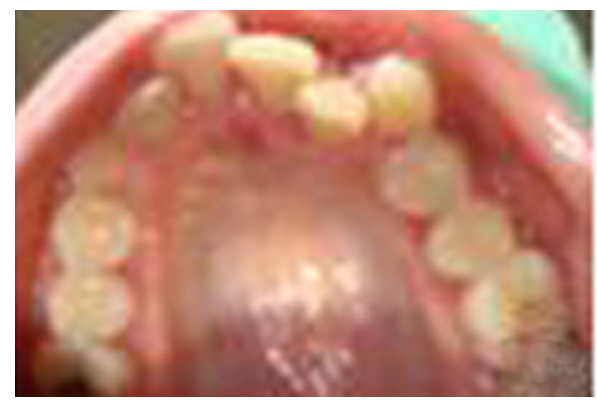

(D)

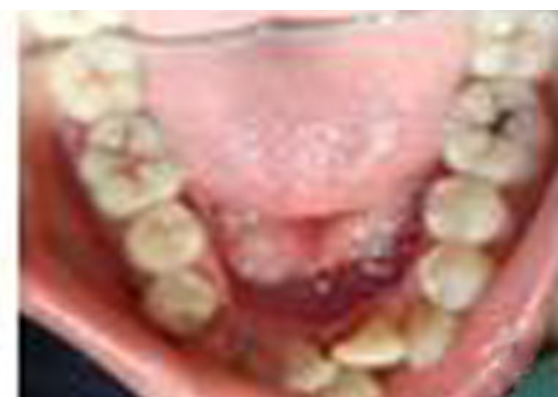

(E)

Gambar 4 . Fotogram intra oral gigi-geligi sebelum perawatan kasus II. Ket : (A) dan (C) Fotogram gigi geligi tampak samping, (B) Fotogram gigi geligi tampak depan, (D) Fotogram intra oral gigi geligi rahang atas, (E) Fotogram intra oral gigi geligi rahang bawah 
Kasus II: Pasien perempuan 18 tahun, datang ke klinik ortodonsia RSCM Prof. Soedomo FKC UGM dengan keluhan gigi berjejal, susah dibersihkan dan gusi sering berdarah (Gambar 3 dan 4).

Pemeriksaan intraoral memperlihatkan hygiene mulut baik. Bentuk lengkung rahang atas $V$ asimetris, rahang bawah berbentuk trapezoid asimetris. Hubungan molar pertama kanan klas III, molar pertama kiri klas I, hubungan kaninus klas I. Overjet pasien $3,25 \mathrm{~mm}$ dan overbite $1,5 \mathrm{~mm}$, terdapat malrelasi crossbite anterior. Pergeseran midline ke kanan, rahang atas $1.0 \mathrm{~mm}$ dan rahang bawah $2.0 \mathrm{~mm}$.

Rencana perawatan pada kasus ini adalah mencabut gigi 31 yang mengalami resesi gingiva karena sudah tidak bisa dipertahankan lagi. Gigigigi diatur dalam lengkung ideal pada determinasi lengkung setelah kedua rahang diekspansi ke lateral. Berdasarkan metode set-up model Kesling agar gigi- gigi dapat tersusun dalam lengkung gigi maka dilakukan pelebaran lengkung gigi pada rahang atas, lebar inter kaninus sebelum perawatan $32 \mathrm{~mm}$ menjadi $36 \mathrm{~mm}$, inter P1 $36 \mathrm{~mm}$ menjadi 42.07 $\mathrm{mm}$, inter P2 awal $42 \mathrm{~mm}$ menjadi $48 \mathrm{~mm}$ dan inter M1 dari $49 \mathrm{~mm}$ menjadi $53 \mathrm{~mm}$ dengan protraksi sebesar $1.0 \mathrm{~mm}$. Pada rahang bawah lebar inter $C$ awal $23 \mathrm{~mm}$ menjadi $25 \mathrm{~mm}$, inter P1 dari 27.50 mm menjadi $35 \mathrm{~mm}$, inter P2 awal $32 \mathrm{~mm}$ menjadi $40 \mathrm{~mm}$ dan inter $\mathrm{M} 1$ dari $40 \mathrm{~mm}$ menjadi $47 \mathrm{~mm}$.
Overjet akhir $3.0 \mathrm{~mm}$ dan overbite $2.0 \mathrm{~mm}$.

Perawatan dilakukan dengan pemasangan alat ortodonti cekat teknik Begg dengan sistem direct bonding untuk koreksi malposisi gigi-gigi individual dan malrelasi crossbite rahang atas dan rahang bawah, vertical loop pada gigi-gigi anterior untuk koreksi gigi berjejal dengan melebarkan lengkung gigi. Kemudian dilanjutkan penyesuaian oklusi dan pemakaian retainer.

Tahap awal dilakukan dengan levelling dan unravelling untuk mengoreksi gigi berjejal parah pada rahang atas dan bawah. Kasus I melalui tahapan pre Begg menggunakan open koil mendorong gigi 13 dan 23 ke distal dengan meligasi gigi yang palatoversi dan linguoversi. Dilanjutkan dengan Australian wire 0.014" pada tahap pertama perawatan dengan teknik Begg dilengkapi dengan vertikal loop yang jumlahnya semakin sedikit sesuai dengan gigi crowding yang akan dikoreksi. (Gambar 5 dan 7)

Kasus II vertical loop antara gigi 13-12, 12 $11,11-21,21-22,22-23,33-32,32-21,21-42,42-$ 43 (Gambar 6). Tahap leveling tercapai setelah satu tahun perawatan. Kasus I setelah 2.5 tahun perawatan, gigi berjejal dan crossbite anterior sudah terkoreksi, pasien juga jadi lebih percaya diri. Overjet dan overbite tetap, saat ini masih dalam perawatan untuk perbaikan interdigitasi.(Gambar 6)

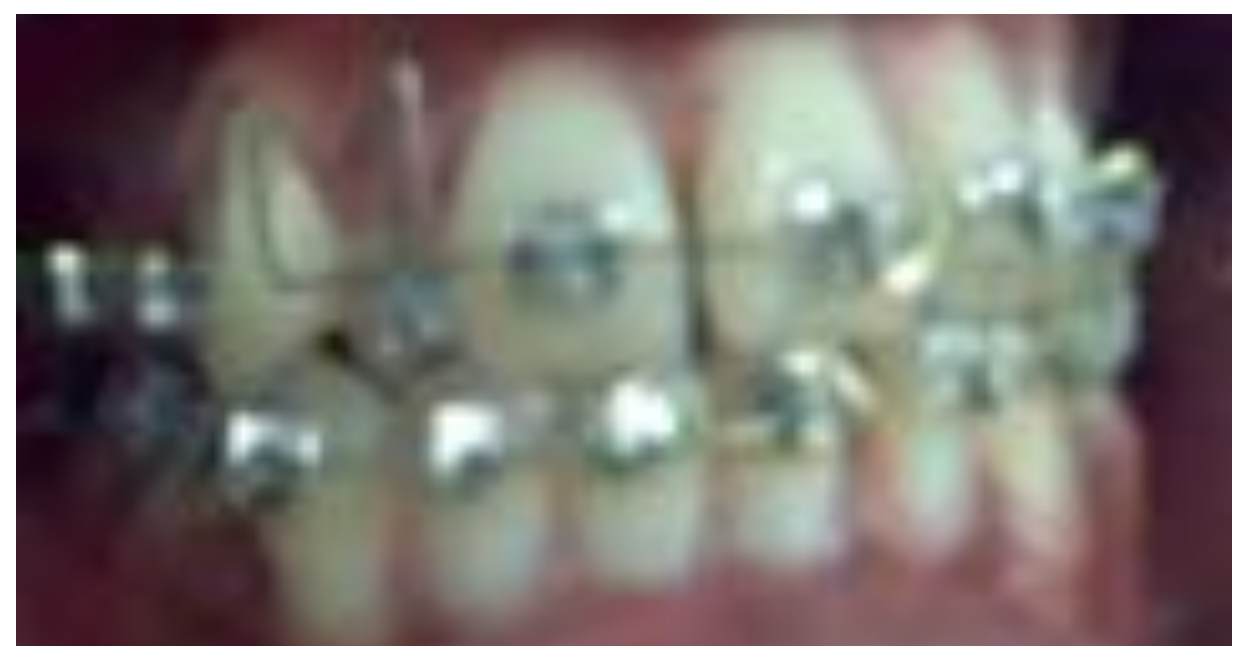

Gambar 5. Kasus I : Tahap I dengan vertikal loop 


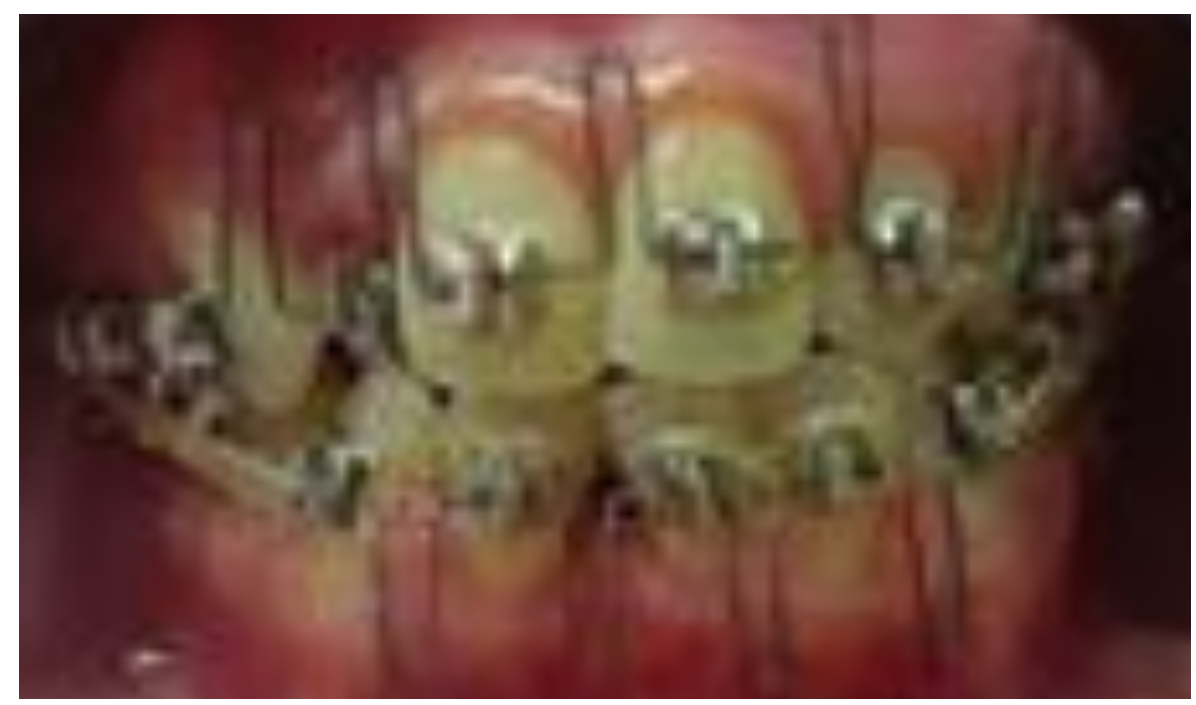

Gambar 6. Kasus II dengan vertikal loop

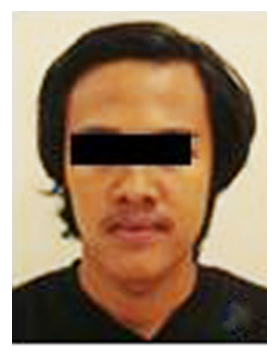

(A)

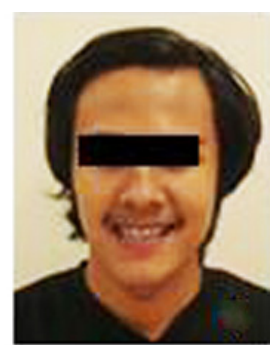

(B)

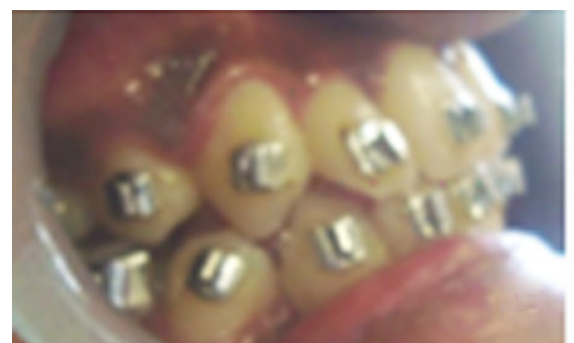

(C)

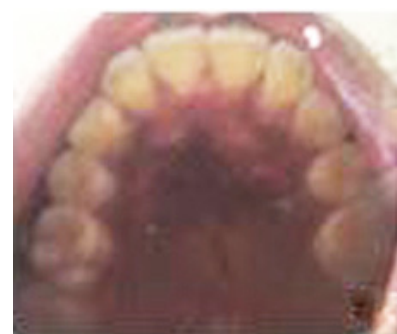

(F)

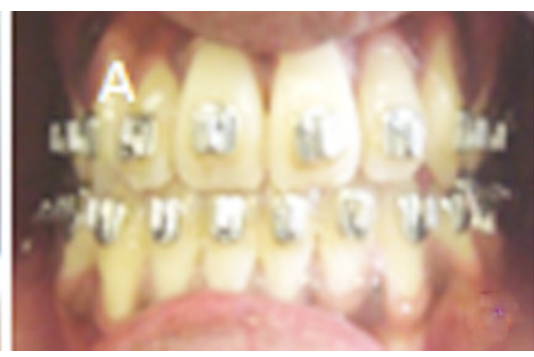

(D)

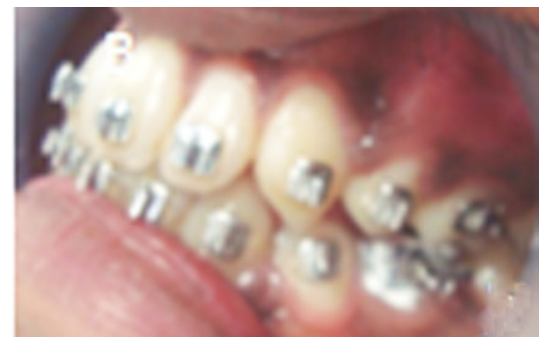

(E)

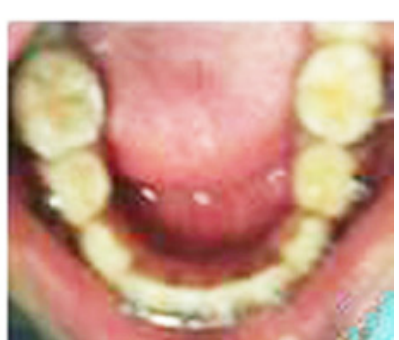

(G)

Gambar 7. Fotogram muka dan intra oral gigi-geligi setelah 2.5 tahun perawatan kasus 1 Ket: (A) Fotogram muka tampak depan, (B) Fotogram muka tampak depan senyum, (C) dan (E) Fotogram gigi geligi tampak samping, (D) Fotogram gigi geligi tampak depan, Fdan GFotogram gigi geligi rahang atas dan rahang bawah tampak oklusal. 


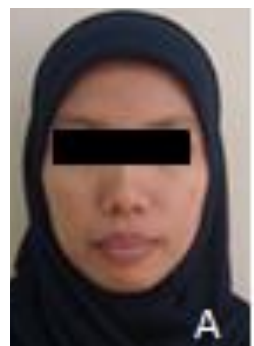

(A)

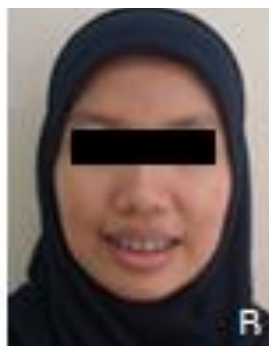

(B)

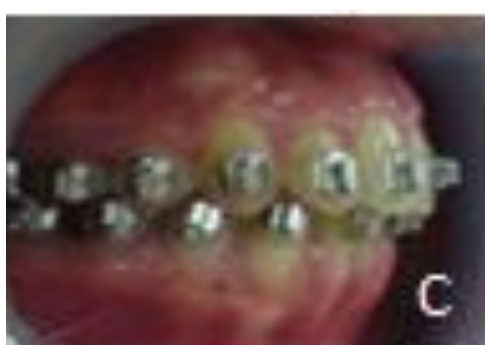

(C)

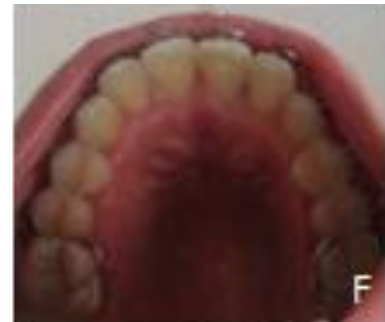

(F)

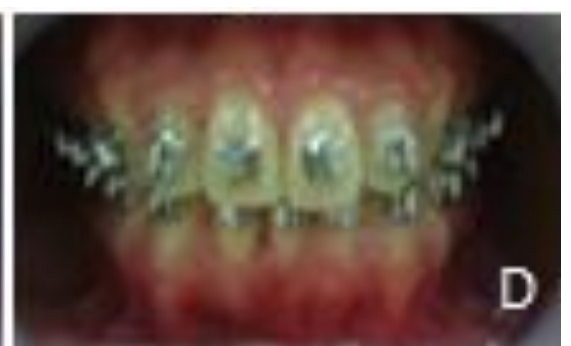

(D)

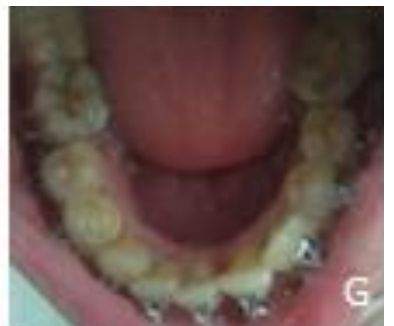

(G)

Gambar 8. Fotogram muka dan intra oral gigi-geligi setelah 2.4 tahun perawatan kasus II. Ket: (A) Fotogram muka tampak depan, (B) Fotogram muka tampak depan senyum, (C) Fotogram muka tampak samping, (D) dan (F) Fotogram gigi geligi tampak samping, (E) Fotogram gigi geligi tampak depan, (G) dan HFotogram gigi geligi rahang atas dan rahang bawah tampak oklusal

Pada kasus II gigi berjejal dan crossbite anterior terkoreksi setelah 2 tahun 4 bulan dan rahang atas sudah terekspansi sesuai dengan analisis ruang (Gambar 6). Perawatan masih berlangsung dalam tahap III koreksi interdigitasi supaya posisi dan kedudukan gigi stabil (Gambar 8).

\section{PEMBAHASAN}

Vertical loop umumnya digunakan untuk mengoreksi gigi berjejal. Jumlah dan panjangnya disesuaikan dengan pengaturan gigi incisivus yang diperlukan. Gerakan horizontal, mesial-distal, bukal lingual yang dihasilkan bertujuan menjajarkan gigi anterior dengan gaya simultan mendorong gigi kaninus ke distal akibat tarikan elastik intermaksiler klas II untuk rahang atas. ${ }^{16}$ Vertical loop juga akan menambah panjang dan kelentingan archwire sehingga dapat melebarkan lengkung gigi dan mengatur malposisi gigi berupa gigi berjejal. ${ }^{3}$ Gigi berjejal yang parah membuat perawatan lebih lama karena melalui tahap pre Begg pada kasus I. Mengganti archwire baru dengan vertical loop yang lebih sedikit dilakukan hingga tiga kali karena disesuaikan dengan koreksi gigi anterior.

Crossbite anterior pada gigi berjejal akan terkoreksi pada tahap I perawatan dengan teknik Begg. Efek kerja dan elastik vertical loop intermaksiler klas II mendorong gigi ke labial sehingga unrevelling dapat dicapai. ${ }^{4.6}$ Pada pasien ini crossbite anterior terkoreksi setelah satu tahun perawatan, dengan gaya yang ringan gigi diligasi dan diaktifkan secara perlahan setiap dua minggu.

Ketidaknyamanan pemakaian vertical loop menjadi salah satu kelemahan dari perawatan dengan teknik Begg,kurangnya estetik dan kesulitan membersihkan gigi juga dialami pasien. ${ }^{2.3}$ Oleh karena itu sangat diperlukan kooperatif pasien khususnya pada tahap 1 perawatan sehingga leveling dan unraveling dapat tercapai dan dilanjutkan pada tahap berikutnya. 


\section{KESIMPULAN}

Penggunaan vertical loop pada perawatan ortodontik cekat dengan teknik Begg sangat efektif mengoreksi gigi berjejal berat dan crossbite anterior. Kooperatif pasien akan sangat berpengaruh pada perawatan ortodontik teknik Begg sehingga dicapai hasil yang memuaskan.

\section{DAFTAR PUSTAKA}

1. Cadman GR. A Vade mecum for the begg technique: technical principles. Am.J.Orthod. 1975; 67(5): 477-512.

2. Daskalogiannakois J. Glossary of orthodontic term. Berlin: 2000. H. 224-225.
3. Bhalajhi SI. Orthodontics the art and science. Ed 3. New Delhi : Arya (MEDI) Publishing House. 2004. H. 392-393.

4. Begg PR, Kesling PC. Begg orthodontic theory and technique. Ed 2. Philadelphia : W.B. Saunders Co; 1977. H.113-150.

5. Kunifec MM. Stability of the impa with reference to the begg method. Angle Orthod. 1971; 41: 264-270.

6. Fletcher CGT. The Begg Appliance and Technique. Briston: John Wright \& Sons (print) Ltd; 1981. H. 15-29

7. Kuftinec MM, Inmam GO. A Comparison of plain versus multilooped arch wires in stage 1 of begg therapy. Am. J. Orthod. 1980; 78 (1): 81-88.

8. Federico VT. Atlas of orthodontic appliances fixed and removable. Ed 16. Hollywood: Orto cycle Co; 1986. 